\title{
Temporal shifts in endophyte bacterial community composition of sessile oak (Quercus petraea) are linked to foliar nitrogen, stomatal length, and herbivory
}

Luigimaria Borruso $^{1}$, Camilla Wellstein ${ }^{1}$, Alessia Bani ${ }^{1}$, Sara Casagrande Bacchiocchi ${ }^{1}$, Ania Margoni ${ }^{1}$, Rita Tonin ${ }^{1}$, Stefan Zerbe ${ }^{1}$, Lorenzo Brusetti ${ }^{\text {Corresp. } 1}$

${ }^{1}$ Faculty of Science and Technology, Free University of Bozen/Bolzano, Bolzano, Italy

Corresponding Author: Lorenzo Brusetti

Email address: lorenzo.brusetti@unibz.it

We studied the relationship between plant functional foliar traits and the endophytic bacterial communities associated in trees, taking the example of sessile oak (Quercus petraea (Matt.) Liebl). Forty-five samples with replicates of eight leaves per sample were collected in spring, summer and autumn. Bacterial community diversity was analyzed via Automated Ribosomal Intergenic Spacer Analysis (ARISA). The leaf traits specific leaf area, level of herbivory, stomatal number, stomatal length, carbon and nitrogen concentration were measured for the leaves of each sample. For statistical analysis, linear mixed effect models, the Canonical Correlation Analysis (CCA) and Non-Parametric Multivariate Analysis of Variance (NPMANOVA) were applied. Herbivory, nitrogen and carbon concentration were significantly different in autumn compared to spring and summer ( $p$ value $<0.05$ ), while stomatal length was differentiated between spring and the other two seasons ( $p$ value < 0.01 ). The seasonal differentiation of the bacterial community structure was explained by the first and second axes (29.7\% and $25.3 \%$, respectively) in the CCA. The bacterial community structure significantly correlated with herbivory, nitrogen concentration and stomatal length. . We conclude that herbivory, nitrogen content, and size of stomatal aperture at the leaf level are important for endophyte colonization in oaks growth in alpine forest environments. 
1 Temporal shifts in endophyte bacterial community composition of sessile oak (Quercus

2 petraea) are linked to foliar nitrogen, stomatal length, and herbivory

3

4 Luigimaria Borruso*, Camilla Wellstein*, Alessia Bani, Sara Casagrande Bacchiocchi, Ania

5 Margoni, Rita Tonin, Stefan Zerbe and Lorenzo Brusetti

6

7 Faculty of Science and Technology, Free University of Bozen-Bolzano, Piazza Università 5, 39100

8 Bolzano, Italy.

9

$10 *$ These authors contributed equally to this work.

12 Corresponding author

13 Lorenzo Brusetti, lorenzo.brusetti@unibz.it

16 Short title: Endophytes and foliar traits in oak 


\section{ABSTRACT}

We studied the relationship between plant functional foliar traits and the endophytic bacterial communities associated in trees, taking the example of sessile oak (Quercus petraea (Matt.) Liebl). Forty-five samples with replicates of eight leaves per sample were collected in spring, summer and autumn. Bacterial community diversity was analyzed via Automated Ribosomal Intergenic Spacer Analysis (ARISA). The leaf traits specific leaf area, level of herbivory, stomatal number, stomatal length, carbon and nitrogen concentration were measured for the leaves of each sample. For statistical analysis, linear mixed effect models, the Canonical Correlation Analysis (CCA) and Non-Parametric Multivariate Analysis of Variance (NPMANOVA) were applied. Herbivory, nitrogen and carbon concentration were significantly different in autumn compared to spring and summer ( $\mathrm{p}$ value $<0.05$ ), while stomatal length was differentiated between spring and the other two seasons ( $\mathrm{p}$ value $<0.01$ ). The seasonal differentiation of the bacterial community structure was explained by the first and second axes $(29.7 \%$ and $25.3 \%$, respectively) in the CCA. The bacterial community structure significantly correlated with herbivory, nitrogen concentration and stomatal length. . We conclude that herbivory, nitrogen content, and size of stomatal aperture at the leaf level are important for endophyte colonization in oaks growth in alpine forest environments.

\section{INTRODUCTION}

One of the major interfaces of biological interaction is between microbiota and plants. While many integrative studies exist, regarding description of bacterial taxa related to host plants and linking bacterial and plant communities across different spatial scales (e.g. symbiosis), temporal scales remain less unexplored. Plant functional traits are increasingly used in ecological research and are a promising avenue to link plant characteristics to environmental factor in interdisciplinary researches (Cornwell et al., 2008; Wellstein et al., 2011). Leaf environment is characterized by foliar functional traits that are hypothesized to affect the hosted microbiome. In the context of the leaf environment of deciduous trees and inhabiting endophytic bacteria, intra-annual dynamics are of special interest.

Endophytic bacteria are ubiquitous inhabitants that colonize the inner parts of most terrestrial plant species beyond the epidermal cell layers (Lodewyckx et al., 2015; Santoyo et al., 
2016). Inside the plant, there are diverse ecological niches in which endophytic bacteria can survive and grow, i.e. within cells, in the intercellular space and in the vascular systems (Jacobs, Bugbee \& Gabrielson, 1985; Bell et al., 1995). Endophytic bacteria are very important to the host plant as they can contribute to the maintenance of its growth and health by, e.g. promoting nutrient acquisition and defense against pathogens (Hirano et al. 1982; Afzal, Khan \& Sessitsch, 2014). This is particularly true for long-lived plant species such as trees and consequently they could affects forest ecosystems (Griffin \& Carson, 2015; Griffin et al., 2016; Griffin et al., 2017; TashiOshnoei, Harighi \& Abdollahzadeh, 2017). Endophytic bacteria have often long-term ecological interactions with the host plants including symbiosis, mutualism and commensalism. They can either be obligate or facultative endophytes. Obligate endophytes are strictly associated with the host plant and they are eventually transferred vertically through plant generations (Santoyo et al., 2016). Facultative endophytes originate from the surrounding environment and they are often included within epidermal cell layers (Hardoim, van Overbeek \& van Elsas, 2008). More complicate is the definition of endophytic pathogens, since historically endophytes have been defined as non-harmful microorganisms (Hallmann et al., 1997). Recently the advances of molecular microbiology have shown the complex dynamics of pathogenesis possibly related to the physiologic behavior of entire microbial communities, rather than of a single strain (Fürnkranz et al., 2012; Erlacher et al., 2014). In this respect, harmful and beneficial endophytes could have in common several mechanisms to colonize and diffuse into plant tissues (Berg, Eberl \& Hartmann, 2005).

Different plant organs have diverse ways of colonization. Free-living soil microorganisms colonize roots (Bulgarelli et al., 2012; Edwards et al., 2015). Leaf endophytic bacteria, especially in case of tall trees, can be acquired from the leaf surface via stomata that represent apertures in the foliar tissue connected to the intercellular space (Ou et al., 2014; Carrell, Carper \& Frank, 2016; Griffin \& Carson 2015). It has been hypothesized that leaves are a suitable surface for exchange with bacteria inhabiting the atmosphere (Bowers et al., 2009). Microbial communities inhabiting leaves, including endophytic bacteria, appear to be rather specialized, given that they share less than $1 \%$ of the bacterial species with soil (Kim et al., 2012).

While numerous publications are focused on leaf epiphytes (Hirano et al., 1982; BalintKurti et al., 2010; Lopez-Velasco et al., 2011), leaf endophytic bacteria remain largely unexplored. Moreover, the possible role of plant functional traits for bacterial community dynamics represents 
80 a research gap. In detail, there are a few studies regarding the temporal dynamic and the environmental factors driving the endophytic bacterial communities associated with forest tree species. Previous works revealed that endophytes are subject to leaf age and leaf developmental stage in grapevine and in elm (Mocali et al., 2003; Bulgari et al., 2014). However, the potential influencers of the endophytic bacteria composition behind leaf aging are still not well understood, especially in forest plants. To the best of our knowledge, no papers have been published so far about a possible linkage between endophytic community assemblages, seasonality and leaf plant traits. Since it well known that stomata represents the main door for bacterial leaf colonization (Underwood, Melotto \& He, 2007), it is reasonable hypothesize that any changes of stomata morphology due to leaf ageing could provoke consequences on the final endophytic community composition. This could reflect the previous results of Mocali et al. (2003) and of Bulgari et al. (2014).

In our study, we aimed to test (i) if there is a temporal gradient associating leaf aging with bacterial turnover and (ii) if foliar plant traits are linked to bacterial community dynamics across time. For this reason, we tested two hypotheses: (i) seasonality affects endophytic bacterial community structure due to changes in foliar chemical composition, and (ii) there is a strict link between endophytic bacterial community structure and foliar traits because some traits, such as stomatal length, could favor the entering of bacterial cells into leaves. To assess the validity of our hypotheses, we investigated a sessile oak forest located in the on Alps in the Northern Italy through an entire growing season.

\section{MATERIALS AND METHODS}

\section{Study site and sampling}

The study area is located in the Monticolo nature reserve on the hillslopes of the Mitterberg at 550 $\mathrm{m}$ a.s.l. in South Tyrol, Italy. The selected study site is representative of the present oak forest, dominated by sessile oak (Quercus petraea (Matt.) Liebl.) with few specimens of Scots pine (Pinus sylvestris L.) in the tree layer as well as of Sweet chestnut (Castanea sativa Mill.) and Manna ash (Fraxinus ornus L.) in the understory. The forest grows on acidic shallow soil above porphyry bedrock on a west-south-west oriented slope. We selected five individuals of sessile oak within the study site, i.e. a circular plot of $15 \mathrm{~m}$ radius $\left(706 \mathrm{~m}^{2}\right)$ representing relatively homogeneous site conditions within the slope. From each tree, we selected three branches taking eight leaves from 
111 the same branch, which were used to assess the endophytic bacteria as well as the foliar functional 112 traits and herbivory. From a previous study, it was clear which types of herbivory were generally 113 present in the study species (Q. petraea) in this forest. Based on Labandeira et al. (2007) seven 114 types of herbivory were found across oaks of the forest. In the present study, we considered only 115 the most frequent herbivory types that would not affect the functional traits' analysis, i.e. margin and hole feeding and sucking Labandeira et al. (2007).

Branches were chosen to have the maximum distance between them, i.e. an angle of $120^{\circ} \mathrm{C}$ between two adjacent branches. In detail, we used three leaves for the functional traits and herbivory measurements and five leaves for the determination of the endophytic bacterial microbial community. We sampled three subsequent seasons in the year 2014, i.e. spring (June $5^{\text {th }}$ ), summer (August $25^{\text {th }}$ ) and autumn (October 20 $0^{\text {th }}$ ). A total of 120 leaves per season was collected, 45 leaves were used for the analysis of functional traits while 75 for the analysis of endophytes.

We measured six functional traits related to important plant functions, i.e. specific leaf area (SLA), leaf nitrogen content $(\mathrm{N})$, leaf carbon content $(\mathrm{C}), \mathrm{C}: \mathrm{N}$ ratio, stomatal number (STNR) and stomatal length (SL). SL is a measure for the size of stomata (Taiz \& Zeiger, 2002). For each season, we determined the SLA of the leaves following standard protocols (Pérez-Harguindeguy et al., 2013). For each leaf, the area was measured the sampling day using a scanner (CanoScan Lide, Canon, Cernusco sul Naviglio, Italy). Subsequently, leaves were oven dried at $70^{\circ} \mathrm{C}$ for 72 hours to obtain their dry weight and the SLA, measured in $\mathrm{mm}^{2} \mathrm{mg}^{-1}$, was calculated (PérezHarguindeguy et al., 2013). N and C were determined using an elemental analyzer (Flash 2000 Organic Elemental Analyzer, Thermo Scientific, Milan, Italy) pooling together the three leaves of each branch.

To measure stomatal characteristics, we applied the clear nail polish method described by Hilu \& Randall (1984) obtaining epidermal impressions of the abaxial surface of each leaves that were examined under an optical microscope (Leica DMLS, Leica Biosystems, Nussloch, Germany) connected to a digital camera. The images were analyzed through the image processing software DeltaPix InSight, (DeltaPix, Smorum, Denmark). The stomata were counted on three fields of view per leaf on a standard counting area at $400 \times$ magnification to determine the stomatal density as number of stomata (STNR) for each standard counting area. On each counting area, the length of the guard cells of stomata (SL) was measured for 15 randomly selected stomata. 
For the measurement of herbivory, the percentage of consumed leaf area was measured scanning the leaf surface (CanoScan LiDE 120, Canon) and calculating the lost area using free software ImageJ (https://imagej.net). Because the great majority of the leaves presented a mixture of the investigated herbivory mediated damage types, for each leaf we quantified the total surface damage caused by the summed herbivory damage types.

\section{DNA extraction and Automated Ribosomal Intergenic Spacer Analysis (ARISA)}

Leaves used for microbiological analysis were processed within 4 hours as follows (Hrynkiewicz K., personal communication): Five leaves for each replicate were disinfected with $70 \%$ ethanol twice each for $3 \mathrm{~min}$. Leaves were then washed with sodium hypochlorite (1.5\%) and TWEEN ${ }^{\circledR}$ 20 for ten minutes, three rinses in sterile, distilled shaking water. Disinfected leaves were grinded to a fine powder under liquid nitrogen using a sterile mortar and pestle. The disinfected samples were stored at $-20^{\circ} \mathrm{C}$. Triplicates of the water used in the last rise were used as negative for PCR amplification and plated on a LB and TSA medium to verify the disinfection protocol. Absence of PCR amplification products was observed. Furthermore, absence of bacterial colonies was observed in all the plates after 10 days of incubation at $30^{\circ} \mathrm{C}$.

DNA was extracted using the Qiagen DNeasy PowerPlant Pro Kit (Qiagen, Milan, Italy) accordingly to the user's manual. Extracted DNA was stored at $-80^{\circ} \mathrm{C}$. The quality and the size of the soil DNA were checked by electrophoresis on 1.2\% agarose gel with a marker (Eurogentec Smart Ladder, Belgio). The absorbance $(260 \mathrm{~nm})$ of $2 \mu \mathrm{l}$ of DNA was used to evaluate the concentration of DNA by NanoVue Spectrophotometer (GE Healthcare, Little Chalfont, UK).

The 16S-23S rRNA Internal Transcribed Spacer (ITS)-PCR was performed using the primers ITSF and ITSReub labeled with 6-FAM according to the chemical and thermal amplification protocol of Cardinale et al. (2004). Capillary electrophoresis was done by STAB Vida Lda. (Caparica, Portugal). Data were investigated via Peak Scanner Software 1.0 (Applied Biosystems, Monza, Italy) and the downstream matrix was normalized and analyzed according to Borruso, Zerbe \& Brusetti (2015).

\section{Data analysis}

PAST software (Hammer, Harper \& Ryan, 2001) was used for the statistical analysis. ANOVA was used to test for differences in the endophytic bacterial richness between seasons. Canonical 
173 correspondence analysis (CCA) of the endophytic microbial community structure in dependence 174 of functional leaf traits and season was performed. Non-Parametric Multivariate Analysis of Variance (NPMANOVA) with Bonferroni corrected $p$-value was applied to investigate differences among the endophytic bacterial communities across the three seasons using Bray-Curtis dissimilarity distance.

Linear discriminant analysis (LDA) effect size (LEfSe) algorithm was used to identify taxa preferentially abundant in each season using default parameters. Briefly, the algorithm identifies the indicator bacterial taxa specialized within the 3 seasons (Segata et al., 2011).

Given the nested design of the experiment, the variation of leaf functional traits across the three seasons was investigated applying linear mixed effect models in R (R Development Core Team 2014 version 3.1.2), using nlme package (Pinheiro et al., 2017). For SLA, SL, STNR, N, C, $\mathrm{C}: \mathrm{N}$ and herbivory we analyzed each trait as response variable, season as fixed variable and, as random factor, we nested the branches from which we sampled the leaves in the respective trees. We log transformed the data that did not satisfied the assumption of variance normality tested with Shapiro test.

\section{RESULTS}

\section{Functional leaf traits and insect-mediated damage types}

Figure 1 and Table 1 shows the results of functional leaf traits investigated in this study across the three sampling seasons. Leaf $\mathrm{N}$ and $\mathrm{C}$ were significantly lower in autumn than in spring and summer $(p<0.01)$. The $\mathrm{C}: \mathrm{N}$ ratio and the level of herbivory were significantly higher in autumn than in spring and summer $(p<0.01)$. SL was significantly higher in spring compared to summer and autumn $(p<0.01)$. STNR and SLA did not show significant differences across the seasons $(p>0.05)$.

\section{Bacterial community structure}

An average of $82 \pm 15$ peaks per sample representing bacterial richness, ranging from 200 bp to $1200 \mathrm{bp}$, were found. No significant results in terms of number of peaks across the three seasons were found (spring $82 \pm 9$; summer $86 \pm 19$ and autumn $79 \pm 14$; ANOVA $p$-value: n.s.). NPANOVA showed significant differences between the bacterial community structure of spring and of autumn $(p<0.001)$, while the bacterial community structures of summer did not cluster 
210

211

212

213

214

215

216

217

218

apart representing a bridge between the two seasons (Table 2). Scattered peaks in between the range 550-850 bp were mostly found in spring and autumn, causing the separation between these two seasons. The LDA showed that 13 ARISA peaks were responsible of the discrimination of spring with respect to the other seasons, 14 peaks were typically discriminant for summer, and 9 for autumn. Most of those peaks were situated in the 550-880 bp slot, confirming the NPANOVA results (Table 3$)$.

\section{Canonical correspondence analysis (CCA)}

Canonical correspondence analysis (CCA) was used to investigate the effects of functional leaf traits and the level of herbivory on endophytic bacterial communities across the seasons. Differentiation is illustrated by the first and second axes in the CCA $(29.7 \%$ and $25.3 \%$, respectively) and the leaf features fitted into the CCA. The CCA ordination diagram (Figure 2) revealed first, that community structure variation appeared along season (temporal sequence) and, second, the existence of relationships between plant foliar traits and endofoliar microbiota across the temporal sequence. In detail, the community variation is related mainly to the level of herbivory, N and SL, and less to STNR, C and SLA (length of vectors in the ordination diagram; Figure 2).

\section{DISCUSSION}

We explored the seasonal diversity behavior via fingerprinting ARISA of the of leaf endophytic bacterial communities. ARISA is a corroborate technique used to investigate bacterial structure variations and the correlations with environmental parameters (Esposito et al., 2013; Borruso, Zerbe \& Brusetti 2015; Pioli et al., 2018) with a comparable robustness as Next Generation Sequencing (van Dorst et al., 2014). Differently by other fingerprinting techniques such as the Length Heterogeneity-PCR or the Denaturing Gradient Gel Electrophoresis of the partial 16S rRNA genes, ARISA can investigate the bacterial community at a deeper taxonomic resolution. Actually, ARISA can reach the subspecies level (Danovaro et al., 2006), via detection of the length polymorphisms of the internal 16S-23S ribosomal DNA spacers within the several copies of ribosomal operons in a bacterial cell (typically from 1 to 10 copies; Gürtler, 1999). Although the endophytic bacterial communities did not show significant differences in alpha diversity across the three seasons, their beta diversity differed mainly between spring and autumn (Table 2 and 
235 Figure 2). These results support the idea of an intimate association between endophytes and the 236 leaf, seen as a dynamic micro-ecosystem that selects for different specific microbial communities along time. Regarding which taxa contribute to the observed difference between seasons, even if the attribution of single ARISA peaks to specific taxa cannot be conclusive due to the real possibility that a peak could be represented by several taxa from different phyla, a putative raw taxon attribution could be done. For instance, according to some authors, many Gram negative bacterial species harbor ITS with tRNA genes (Triplett et al., 1999; Ranjard et al., 2000). Their spacers usually range between 500 and 800 bp (Gürtler \& Stanisich, 1996). On the other side Gram positive bacteria harbor shorter ITS, while rhizobia have very long spacers, often longer than 1000 bp (Gürtler \& Stanisich, 1996). The length range between 500 and $600 \mathrm{bp}$ is what had been observed in our case differentiating spring to autumn. We could hypothesize that seasons have an effect on the diversity of Gram negative bacteria. A different answer of Gram negative bacteria rather than Gram positive bacteria due to different environmental pressures had already been observed in other plant-related compartments, such as rhizosphere (Ciccazzo et al., 2014).

Leaves have been traditionally considered as "short-lived environment", where specialized bacteria can dynamically colonize new niches and leave others according to the leaf continuous modifications over seasons (Vorholt, 2012). Bulgari et al. (2014) hypothesized that the endophytic communities in Vitis vinifera should remain stable across the seasons in absence of bacterial plant pathogens such as phytoplasma. However, this is in contrast with our findings and those of other researchers. Influence of the seasonality on endophytic microbial community composition associated with different tree species (i.e. Acer negundo, Ulmus pumila, and U. parvifolia) were also found by Shen \& Fulthorpe (2015). Moreover, others observed that the bacterial community composition in the phyllosphere was primarily driven by temporal changes and community succession (Copeland et al., 2015). In order to shed light on the processes behind community changes, we explored the role of leaf functional traits in bacterial structure dynamics. In fact, previous studies investigated the effect of migration and community succession in the phyllosphere microbiome and suggested that colonization, persistence, and succession of the community may be key-factors driving the phyllosphere microbiome (Redford \& Fierer, 2009; Shade, McManus \& Handelsman, 2013; Maignien et al., 2014; Copeland et al., 2015). The relevance of environmental conditions such as temperature optima of the bacteria or the changing physiology of tree host species have been discussed for their possible effects (Jansson \& Douglas, 2007). 
However, previous studies did not look deeper into possible correlations in terms of plant functional characteristics behind the observed dynamical processes of the microbiome.

Given that we found a clear endophytic seasonal variation, it is highly interesting to understand better the potential leaf-level characteristics possibly associated with bacteria community compositional variation. In fact, based on our results, we suggest that foliar characteristics related to leaf-level herbivory, nutrient contents and stomatal length aperture may affect directly the bacterial community composition over time.

As a matter of fact, herbivory could be an effective way to inoculate microbial insects symbionts, commensals and pathogens into plant tissues. It is the case, for instance, of phytoplasmas inoculated into grapevine by Hemiptera-like leafhoppers (Gonellaet al., 2008; Alma et al., 2018). In our forest plots, several herbivory traces have been recorded during the experiments. In general, the majority of insect species causes single distinct damages on leaves (Labandeira et al., 2007). From a survey on Quercus petraea's leaves in the same forest, the herbivory damage types were recorded by using three leaves per individual with a total amount of 180 plant individuals. Seven types of damages were recorded: Margin feeding (detected in the $90 \%$ of the observed leaves), surface feeding (61\%), hole feeding (45\%), sucking (31\%), skeletonization (12\%), mining (12\%) and leaf rolling (9\%). This number of herbivory damage types justifies the perception of a relatively high insect diversity since it has been shown that there is a quantitative relation between the richness of damage types and the insect species richness (Carvalho et al., 2015). Phloem-feeding insects could act as inoculating vectors of entire bacterial communities between different plant individuals, moving bacterial strains from a tree to another (Lòpez-Fernàndez et al., 2017). It is reasonable to hypothesize that, as insect abundance and diversity may change due to season variation (Grimbacher et al., 2018), also the endophytic bacterial communities potentially transmissible among tree individuals change, hence contributing to our observed results.

In addition, stomata are the major door for the leaf colonization by foliar bacterial pathogens (Underwood, Melotto \& He, 2007; Melotto,Underwood \& He, 2008). To counteract the entrance of potential pathogens, plants have evolved a number of mechanisms to detect and remove pathogenic bacterial cells from their tissues, regulating to some extent the access of bacteria through stomata (Gimenez-Ibanez et al., 2017). This is due to the ability of plants in detecting specific molecular signals such as bacterial lipopolysaccharides, flagellins or elongation 
297 factors (Underwood, Melotto \& He, 2007). Consequently, plants close the majority of their leaf 298 stomata. However, bacteria may overcome this mechanism of defense, entering into the leaf intercellular spaces by taking advantage of those stomatal guard cells that are not able to react to the presence of bacterial signals (Underwood, Melotto \& He, 2007). We observed that SL could be associated with the shaping of endophytic community structure, especially in spring (Fig. 2). This observation could mirror the entrance of specific as well as unspecific bacterial strains into leaves when the leaves were growing. Actually, Gailing et al (2008) found that in Quercus robur the variability of stomatal number is genetically determined. Additionally, Turner \& Heichel (1977) demonstrated for Quercus rubra that SL reaches it maximum before leaves developed their maximum areas in late spring. It is plausible that bacteria enter into the leaf as soon as it has flashed, and then a sort of successional dynamic is established until reaching an equilibrium once the stomata shape are fixed. The difference in SL between spring leaves from summer and autumn leaves may depend by the contraction of the leaf pool available for measurements caused by the loss of the leaves that occur both naturally during the vegetative season (Brooke et al., 1996) and because of the detected herbivory.

Finally, leaf nutrient contents and their changes correlate with bacteria dynamics (Kembel et al., 2014). It has been shown that endophytic bacterial taxa able to fix nitrogen occur in oak species (Tashi-Oshnoei, Harighi \& Abdollahzadeh, 2017), in the wild poplar Populus trichocarpa leaves (Doty et al., 2016), and in Pinus flexilis needles (Moyes et al., 2016), helping plants establishment and growth in N-limited environment. Eventually, a drop in leaf nitrogen content could challenge bacterial shifts towards nitrogen-fixing taxa and in contrast to denitrifying bacteria.

Our results of diminishing nutrients such as $\mathrm{C}$ and $\mathrm{N}$ with leaf aging is in line with other studies ( $\mathrm{Li}$ et al., 2017), while other functional traits related to the stomata, such as STNR and SLA did not vary significantly along season. Another study on leaf traits of seven different woody species grown under experimental conditions shed light on their seasonal variation (Römermann et al., 2016). The results of this study highlight that SLA and stomatal size were robust traits across season in terms of small intraspecific variation. In comparison, our species $Q$. petraea also has stable STNR and SLA levels. However, as explained above, the changes in SL most likely reflect changes in the leaves' pool of the forest as the leaves' pool was diminished by herbivory and browsing that led to leaf loss after the spring season. Moreover, herbivory, that increases over 
328 season due to elongated exposure time, can have a direct impact on endophytic bacteria as well as an indirect effect by influencing other leaf characteristics. For example, the open structures of the leaf, limited to the size and number of stomata in intact leaves, are largely modified by herbivory that exposes further leaf tissue. Due to the increasing rate of changes that can be assumed with aging (Suzuki et al., 1987; Chavana-Bryant et al., 2017), we expect that leaf characteristics exert a differential impact during aging on the bacterial community.

\section{Conclusions}

Based on our findings, we suggest that herbivory, nitrogen content, and size of stomatal aperture at the leaf level are important for endophyte colonization in oaks growth in alpine forest environments. We argued that herbivory and stomata length are important doors from where bacteria enter to colonize the leaf. As possible consequence, the endophytic community assemblages switch during the progression of seasons, when the stomatal length increases during the leaf germination and elongation, and when the chemical characteristics of the leaf are different from those in autumn.

\section{Acknowledgements}

We thank Prof. Giustino Tonon for the access to the Monticolo site area, managed under the NITROFOR project.

\section{References}

Afzal M, Khan QM, Sessitsch A. 2014. Endophytic bacteria: Prospects and applications for the phytoremediation of organic pollutants. Chemosphere 117:232-242 DOI 10.1016/j.chemosphere.2014.06.078.

Alma A, Lessio F, Gonella E, Picciau L, Mandrioli M, Tota F. 2018. New insights in phytoplasma-vector interaction: acquisition and inoculation of flavescence dorée phytoplasma by Scaphoideus titanus adults in a short window of time. Annals of Applied Biology 173:55-62. DOI: 10.1111/aab.12433.

Balint-Kurti P, Simmons SJ, Blum JE, Ballaré CL, Stapleton AE. 2010. Maize leaf epiphytic bacteria diversity patterns are genetically correlated with resistance to fungal pathogen infection. Molecular Plant-Microbe Interactions 23:473-484 DOI 10.1094/MPMI-23-4- 
0473.

Bell CR, Dickie GA, Harvey WLG, Chan JWYF. 1995. Endophytic bacteria in grapevine. Canadian Journal of Microbiology 41:46-53. DOI 10.1139/m95-006.

Berg G, Eberl L, Hartmann A. 2005. The rhizosphere as a reservoir for opportunistic human pathogenic bacteria. Environmental Microbiology 7:1673-1685. DOI: 10.1111/j.14622920.2005.00891.x.

Borruso L, Zerbe S, Brusetti L. 2015. Bacterial community structures as a diagnostic tool for watershed quality assessment. Research in Microbiology 166:38-44. DOI 10.1016/j.resmic.2014.11.004.

Bowers RM, Lauber CL, Wiedinmyer C, Hamady M, Hallar AG, Fall R, Knight R, Fierer N. 2009. Characterization of airborne microbial communities at a high-elevation site and their potential to act as atmospheric ice nuclei. Applied and Environmental Microbiology 75:51215130. DOI 10.1128/AEM.00447-09.

Brooke AMDL, Jones PJ, Vickery JA, Waldren S. 1996. Seasonal patterns of leaf growth and loss, flowering and fruiting on a subtropical central pacific island. Biotropica 28:164-179

Bulgarelli D, Rott M, Schlaeppi K, Ver Loren van Themaat E, Ahmadinejad N, Assenza F, Rauf P, Huettel B, Reinhardt R, Schmelzer E, Peplies J, Gloeckner FO, Amann R, Eickhorst T, Schulze-Lefert P. 2012. Revealing structure and assembly cues for Arabidopsis root-inhabiting bacterial microbiota. Nature 488:91-95. DOI 10.1038 /nature11336.

Bulgari D, Casati P, Quaglino F, Bianco PA. 2014. Endophytic bacterial community of grapevine leaves influenced by sampling date and phytoplasma infection process. $B M C$ Microbiology 14:198. DOI 10.1186/1471-2180-14-198.

Cardinale M, Brusetti L, Quatrini P, Borin S, Puglia AM, Rizzi A, Sorlini C, Corselli C, Zanardini E, Daffonchio D. 2004. Comparison of different primer sets for use in automated ribosomal intergenic spacer analysis of complex bacterial communities. Applied and Environmental Microbiology 70:6147-6156. DOI 10.1128/AEM.70.10.6147.

Carrell AA, Carper DL, Frank AC. 2016. Subalpine conifers in different geographical locations host highly similar foliar bacterial endophyte communities. FEMS Microbiology Ecology 92:1-9. DOI 10.1093/femsec/fiw124.

Carvalho DO, Mckemey AR, Garziera L, Lacroix R, Donnelly C, Alphey L, Malavasi A, 
Capurro M. 2015. Suppression of a field population of Aedes aegypti in Brazil by sustained release of transgenic male mosquitoes. PloS ONE 9(5):1-15. DOI: 10.1371/journal.pntd.0003864.

Chavana-Bryant C, Malhi Y, Wu J, Asner GP, Anastasiou A, Enquist BJ, Cosio Caravasi EG, Doughty CE, Saleska SR, Martin R., Gerard FF. 2017. Leaf aging of Amazonian canopy trees as revealed by spectral and physiochemical measurements. New Phytologist 214:1049-1063. DOI: 10.1111/nph.13853.

Copeland JK, Yuan L, Layeghifard M, Wang PW, Guttman DS. 2015. Seasonal community succession of the phyllosphere microbiome. Molecular Plant-Microbe Interactions 28:274285. DOI 10.1094/MPMI-10-14-0331-FI.

Cornwell WK, Cornelissen JHC, Amatangelo K, Dorrepaal E, Eviner VT, Godoy O, Hobbie SE, Hoorens B, Kurokawa H, Pérez-Harguindeguy N, Quested HM, Santiago LS, Wardle DA, Wright IJ, Aerts R, Allison SD, Van Bodegom P, Brovkin V, Chatain A, Callaghan TV, Díaz S, Garnier E, Gurvich DE, Kazakou E, Klein JA, Read J, Reich PB, Soudzilovskaia NA, Vaieretti MV, Westoby M. 2008. Plant species traits are the predominant control on litter decomposition rates within biomes worldwide. Ecology Letters 11:1065-1071. DOI 10.1111/j.1461-0248.2008.01219.x.

Danovaro R, Luna GM, Dell'Anno A, Pietrangeli B. 2006. Comparison of two fingerprinting techniques, terminal restriction fragment length polymorphism and automated ribosomal intergenic spacer analysis, for determination of bacterial diversity in aquatic environments. Applied and Environmental Microbiology 72:5982-5989. DOI: 10.1128/AEM.01361-06.

van Dorst J, Bissett A, Palmer AS, Brown M, Snape I, Stark JS, Raymond B, McKinlay J, Ji M, Winsley T, Ferrari BC. 2014. Community fingerprinting in a sequencing world. FEMS Microbiology Ecology 89:316-330. DOI 10.1111/1574-6941.12308.

Doty SL, Sher AW, Fleck ND, Khorasani M, Bumgarner RE, Khan Z, Ko AWK, Kim SH, DeLuca TH. 2016. Variable nitrogen fixation in wild Populus. PLOS ONE 11:1-22. DOI: 10.1371/journal.pone.0155979.

Edwards J, Johnson C, Santos-Medellín C, Lurie E, Podishetty NK, Bhatnagar S, Eisen JA, Sundaresan V. 2015. Structure, variation, and assembly of the root-associated microbiomes of rice. Proceedings of the National Academy of Sciences of the United States of America 112:E911-E920. DOI 10.1073/pnas.1414592112. 
Erlacher A, Cardinale M, Grosch R, Grube M, Berg G. 2014. The impact of the pathogen Rhizoctonia solani and its beneficial counterpart Bacillus amyloliquefaciens on the indigenous lettuce microbiome. Frontiers in Microbiology 5:1-8. DOI: 10.3389/fmicb.2014.00175.

Esposito A, Ciccazzo S, Borruso L, Zerbe S, Daffonchio D, Brusetti L. 2013. A three-scale analysis of bacterial communities involved in rocks colonization and soil formation in high mountain environments. Current Microbiology 67:472-479. DOI 10.1007/s00284-013-03919.

Fürnkranz M, Lukesch B, Müller H, Huss H, Grube M, Berg G. 2012. Microbial Diversity Inside Pumpkins: Microhabitat-Specific Communities Display a High Antagonistic Potential Against Phytopathogens. Microbial Ecology 63:418-428. DOI: 10.1007/s00248-011-99424.

Gailing O, Langenfeld-Heyser R, Polle A, Finkeldey R. 2008. Quantitative trait loci affecting stomatal density and growth in a Quercus robur progeny: implications for the adaptation to changing environments. Global Change Biology 14:1934-1946. DOI: 10.1111/j.13652486.2008.01621.x

Gimenez-Ibanez S, Boter M, Ortigosa A, García-Casado G, Chini A, Lewsey MG, Ecker JR, Ntoukakis V, Solano R. 2017. JAZ2 controls stomata dynamics during bacterial invasion. New Phytologist 213:1378-1392. DOI 10.1111/nph.14354.

Gonella E, Negri I, Marzorati M, Brusetti L, Pajoro M, Mandrioli M, Tedeschi R, Daffonchio D, Alma A. 2008. Study of the bacterial community affiliated to Hyalesthes obsoletus, the insect vector of " bois noir" phytoplasma of grape. Bulletin of Insectology 61:221-222.

Griffin EA, Carson WP. 2015. The Ecology and Natural History of Foliar Bacteria with a Focus on Tropical Forests and Agroecosystems. Botanical Review 81:105-149. DOI: 10.1007/s12229-015-9151-9.

Griffin EA, Traw MB, Morin PJ, Pruitt JN, Wright SJ, Carson WP. 2016. Foliar bacteria and soil fertility mediate seedling performance: a new and cryptic dimension of niche differentiation. Ecology, Ecological Society of America 97:2998-3008. DOI: 10.1002/ecy.1537.

Griffin EA, Wright SJ, Morin PJ, Carson WP. 2017. Pervasive interactions between foliar microbes and soil nutrients mediate leaf production and herbivore damage in a tropical forest. 
The New phytologist 216:99-112. DOI: 10.1111/nph.14716.

Grimbacher PS, Edwards W, Liddell MJ, Nelson PN, Nichols C, Wardhaugh CW, Stork NE. 2018. Temporal variation in abundance of leaf litter beetles and ants in an Australian lowland tropical rainforest is driven by climate and litter fall. Biodiversity and Conservation 27(10):2625-2640. DOI: 10.1007/s10531-018-1558-2.

Gürtler V. 1999. The role of recombination and mutation in 16S-23S rDNA spacer rearrangements. Gene 238:241-252. DOI: 10.1016/S0378-1119(99)00224-3.

Hallmann J, Quadt-Hallmann A, Mahaffee WF, Kloepper JW. 1997. Bacterial endophytes in agricultural crops. Canadian Journal of Microbiology 43:895-914. DOI: 10.1139/m97-131.

Hammer Ø, Harper DAT, Ryan PD. 2001. PAST: Paleontological statistics software package for education and data analysis. Palaeontologia Electronica 4:1-9. DOI 10.1016/j.bcp.2008.05.025.

Hardoim PR, van Overbeek LS, van Elsas JD. 2008. Properties of bacterial endophytes and their proposed role in plant growth. Trends in Microbiology 16:463-471. DOI 10.1016/j.tim.2008.07.008.

Hilu KW, Randall JL. 1984 Convenient method for studying grass leaf epidermis. Taxon 33:413415 . doi: $10.2307 / 1220980$

Hirano SS, Nordheim EV, Arny DC, Upper CD. 1982. Lognormal distribution of epiphytic bacterial populations on leaf surfaces. Applied and Environmental Microbiology 44:695-700.

Jacobs MJ, Bugbee WM, Gabrielson DA. 1985. Enumeration, location, and characterization of endophytic bacteria within sugar beet roots. Canadian Journal of Botany 63:1262-1265. DOI 10.1139/b85-174.

Jansson S, Douglas CJ. 2007. Populus: A model system for plant biology. Annual Review of Plant Biology 58:435-458. DOI 10.1146/annurev.arplant.58.032806.103956.

Kembel SW, O'Connor TK, Arnold HK, Hubbell SP, Wright SJ, Green JL. 2014. Relationships between phyllosphere bacterial communities and plant functional traits in a neotropical forest. Proceedings of the National Academy of Sciences of the United States of America 111:13715-13720. DOI: 10.1073/pnas.1216057111.

Kim M, Singh D, Lai-Hoe A, Go R, Rahim RA, Ainuddin AN, Chun J, Adams JM. 2012. Distinctive phyllosphere bacterial communities in tropical trees. Microbial Ecology 63:674681. DOI: 10.1007/s00248-011-9953-1. 
Labandeira, C.C., Wilf, P., Johnson, K.R., and Marsh, F. 2007. Guide to Insect (and Other) Damage Types on Compressed Plant Fossils. Version 3.0. Smith-sonian Institution, Washington, D.C. 25 p.

Li H, Crabbe MJC, Xu F, Wang W, Ma L, Niu R, Gao X, Li X, Zhang P, Ma X, Chen H. 2017. Seasonal variations in carbon, nitrogen and phosphorus concentrations and $C: N: P$ stoichiometry in different organs of a Larix principis-rupprechtii Mayr. plantation in the Qinling Mountains, China. Plos One 12:e0185163. DOI 10.1371/journal.pone.0185163.

Lodewyckx C, Vangronsveld J, Porteous F, Moore ERB, Taghavi S, Mezgeay, Max AU - der Lelie, Daniel van Lodewyckx C, Vangronsveld J, Porteous F, Moore ERB, Taghavi S, Mezgeay M, van der Lelie D. 2015. Endophytic bacteria and their potential applications. Critical Reviews in Plant Sciences 2689:37-41. DOI 10.1080/0735-260291044377.

Lòpez-Fernàndez S, Mazzoni V, Pedrazzoli F, Pertot I, Campisano A. 2017. A phloem-feeding insect transfers bacterial endophytic communities between grapevine plants. Frontiers in Microbiology 8:1-17. DOI: 10.3389/fmicb.2017.00834.

Lopez-Velasco G, Welbaum GE, Boyer RR, Mane SP, Ponder MA. 2011. Changes in spinach phylloepiphytic bacteria communities following minimal processing and refrigerated storage described using pyrosequencing of 16S rRNA amplicons. Journal of Applied Microbiology 110:1203-1214. DOI 10.1111/j.1365-2672.2011.04969.x.

Maignien L, DeForce EA, Chafee ME, Murat Eren A, Simmons SL. 2014. Ecological succession and stochastic variation in the assembly of Arabidopsis thaliana phyllosphere communities. mBio 5:1-10. DOI 10.1128/mBio.00682-13.

Melotto M, Underwood W, He SY. 2008. Role of stomata in plant innate immunity and foliar bacterial diseases. Annual Review of Phytopathology 46:101-122. DOI: 10.1146/annurev.phyto.121107.104959.

Mocali S, Bertelli E, Di Cello F, Mengoni A, Sfalanga A, Viliani F, Caciotti A, Tegli S, Surico G, Fani R. 2003. Fluctuation of bacteria isolated from elm tissues during different seasons and from different plant organs. Research in Microbiology 154:105-114. DOI 10.1016/S0923-2508(03)00031-7.

Moyes AB, Kueppers LM, Pett-Ridge J, Carper DL, Vandehey N, O’Neil J, Frank AC. 2016. Evidence for foliar endophytic nitrogen fixation in a widely distributed subalpine conifer. New Phytologist 210:657-668. DOI 10.1111/nph.13850. 
Ou X, Gan Y, Chen P, Qiu M, Jiang K, Wang G. 2014. Stomata prioritize their responses to multiple biotic and abiotic signal inputs. PLoS ONE 9:3-10. DOI 10.1371/journal.pone.0101587.

Pérez-Harguindeguy N, Díaz S, Garnier E, Lavorel S, Poorter H, Jaureguiberry P, BretHarte MS, Cornwell WK, Craine JM, Gurvich DE, Urcelay C, Veneklaas EJ, Reich PB, Poorter L, Wright IJ, Ray P, Enrico L, Pausas JG, De Vos AC, Buchmann N, Funes G, Quétier F, Hodgson JG, Thompson K, Morgan HD, Ter Steege H, Van Der Heijden MGA, Sack L, Blonder B, Poschlod P, Vaieretti MV, Conti G, Staver AC, Aquino S, Cornelissen JHC. 2013. New handbook for standardised measurement of plant functional traits worldwide. Australian Journal of Botany 61:167-234. DOI 10.1071/BT12225.

Pinheiro J, Bates D, DebRoy S, Sarkar D, R Core Team. 2017. nlme: Linear and Nonlinear Mixed Effects Models. Available at: https://cran.r-project.org/web/packages/nlme/nlme.pdf.

Pioli S, Antonucci S, Giovannelli A, Traversi ML, Borruso L, Bani A, Brusetti L, Tognetti R. 2018. Community fingerprinting reveals increasing wood-inhabiting fungal diversity in unmanaged Mediterranean forests. Forest Ecology and Management 408:202-210. DOI 10.1016/j.foreco.2017.10.052.

Redford AJ, Fierer N. 2009. Bacterial succession on the leaf surface: A novel system for studying successional dynamics. Microbial Ecology 58:189-198. DOI 10.1007/s00248-009-9495-y.

Römermann C, Bucher SF, Hahn M, Bernhardt-Römermann M. 2016. Plant functional traits - fixed facts or variable depending on the season? Folia Geobotanica 51:143-159. DOI 10.1007/s12224-016-9250-3.

Santoyo G, Moreno-Hagelsieb G, del Carmen Orozco-Mosqueda M, Glick BR. 2016. Plant growth-promoting bacterial endophytes. Microbiological Research 183:92-99. DOI 10.1016/j.micres.2015.11.008.

Segata N, Izard J, Waldron L, Gevers D, Miropolsky L, Garrett WS, Huttenhower C. 2011. Metagenomic biomarker discovery and explanation. Genome Biology 12:R60 DOI: 10.1186/gb-2011-12-6-r60.

Shade A., McManus P., Handelsman J. 2013. Unexpected diversity during community succession in the apple. mBio 4:1-12. DOI 10.1128/mBio.00602-12.

Shen SY., Fulthorpe R. 2015. Seasonal variation of bacterial endophytes in urban trees. Frontiers in Microbiology 6:1-13. DOI 10.3389/fmicb.2015.00427. 
545 Suzuki S, Nakamoto H, Ku MS, Edwards GE. 1987. Influence of leaf age on photosynthesis,

546

547

548

549

550

551

552

553

554

555

556 enzyme activity, and metabolite levels in wheat. Plant physiology 84:1244-8.

Taiz L, Zeiger E. 2006. Plant Physiology. Sinauer Associates, Inc, Sunderland

Tashi-Oshnoei F, Harighi B, Abdollahzadeh J. 2017. Isolation and identification of endophytic bacteria with plant growth promoting and biocontrol potential from oak trees. Forest Pathology 47:1-8. DOI 10.1111/efp.12360.

Turner NC, Heichel GH. 1977. Stomatal development and seasonal changes in diffusive resistance of primary and regrowth foliage of red oak (Quercus rubra L.) and red maple (Acer rubrum L.). New Phytol 78:71-81 . doi: 10.1111/j.1469-8137.1977.tb01544.x

Underwood W, Melotto M, He SY. 2007. Role of plant stomata in bacterial invasion. Cellular Microbiology 9:1621-1629. DOI: 10.1111/j.1462-5822.2007.00938.x.

Vorholt JA. 2012. Microbial life in the phyllosphere. Nature Reviews Microbiology 10:828-840. DOI 10.1038/nrmicro2910.

Wellstein C, Schröder B, Reineking B, Zimmermann NE. 2011. Understanding species and community response to environmental change - A functional trait perspective. Agriculture, Ecosystems and Environment 145:1-4. DOI 10.1016/j.agee.2011.06.024. 


\section{Figure and Tables captions}

Figure 1 Differences of foliar traits $(\mathrm{N}=$ nitrogen, $\mathrm{C}=$ carbon, $\mathrm{C}: \mathrm{N}=$ carbon/nitrogen ratio, SLA= specific leaf area, $\mathrm{SL}=$ stomatal length, $\mathrm{STNR}=$ stomatal number per reference area, $\mathrm{HERB}=$ level of herbivory) among three seasons (spring, summer, autumn). Significant differences according to linear mixed effect models followed by post-hoc test are indicated by different lower case letters. Graphics without letters were not significant. Detailed results of linear mixed effect models are given in Table 3.

Figure 2 CCA analysis of endophytic communities across a temporal sequence (spring: blue dots; summer: green dots; autumn: red dots) and plant foliar traits. CCA was calculated with the following plant foliar traits: HERB = level of herbivory; STNR = number of stomata; SLA = specific leaf area; $\mathrm{SL}=$ length of stomata; $\mathrm{N}=$ leaf nitrogen content; $\mathrm{C}=$ leaf carbon content.

Table 1 Results of linear mixed effect models for each trait . A: leaf nitrogen content; B: leaf carbon content; C: C:N ratio; D: specific leaf area (SLA); E: stomatal length (SL); F: stomatal number /STNR): G: herbivory level. Each single trait was analyzed as response variable, season as fixed variable and branches nested in the respective trees as random variable. The basic level (intercept) corresponds to the spring season.

Table $2 P$ value results from Non-Parametric MANOVA (NPMANOVA) with Bonferroni corrected $p$ value among endophytic bacterial communities across the three seasons (Bray-Curtis dissimilarity).

Table 3 OTU biomarkers characterizing each single season on the basis of the Linear Discriminant Analysis effect size. 
Figure 1

Differences of foliar traits among the three analyzed seasons

Differences of foliar traits $(\mathrm{N}=$ nitrogen, $\mathrm{C}=$ carbon, $\mathrm{C}: \mathrm{N}=$ carbon/nitrogen ratio, $\mathrm{SLA}=$ specific leaf area, $\mathrm{SL}=$ stomatal length, $\mathrm{STNR}=$ stomatal number per reference area, HERB $=$ level of herbivory) among three seasons (spring, summer, autumn). Significant differences according to linear mixed effect models followed by post-hoc test are indicated by different lower case letters. Graphics without letters were not significant. Detailed results of linear mixed effect models are given in Table 3.
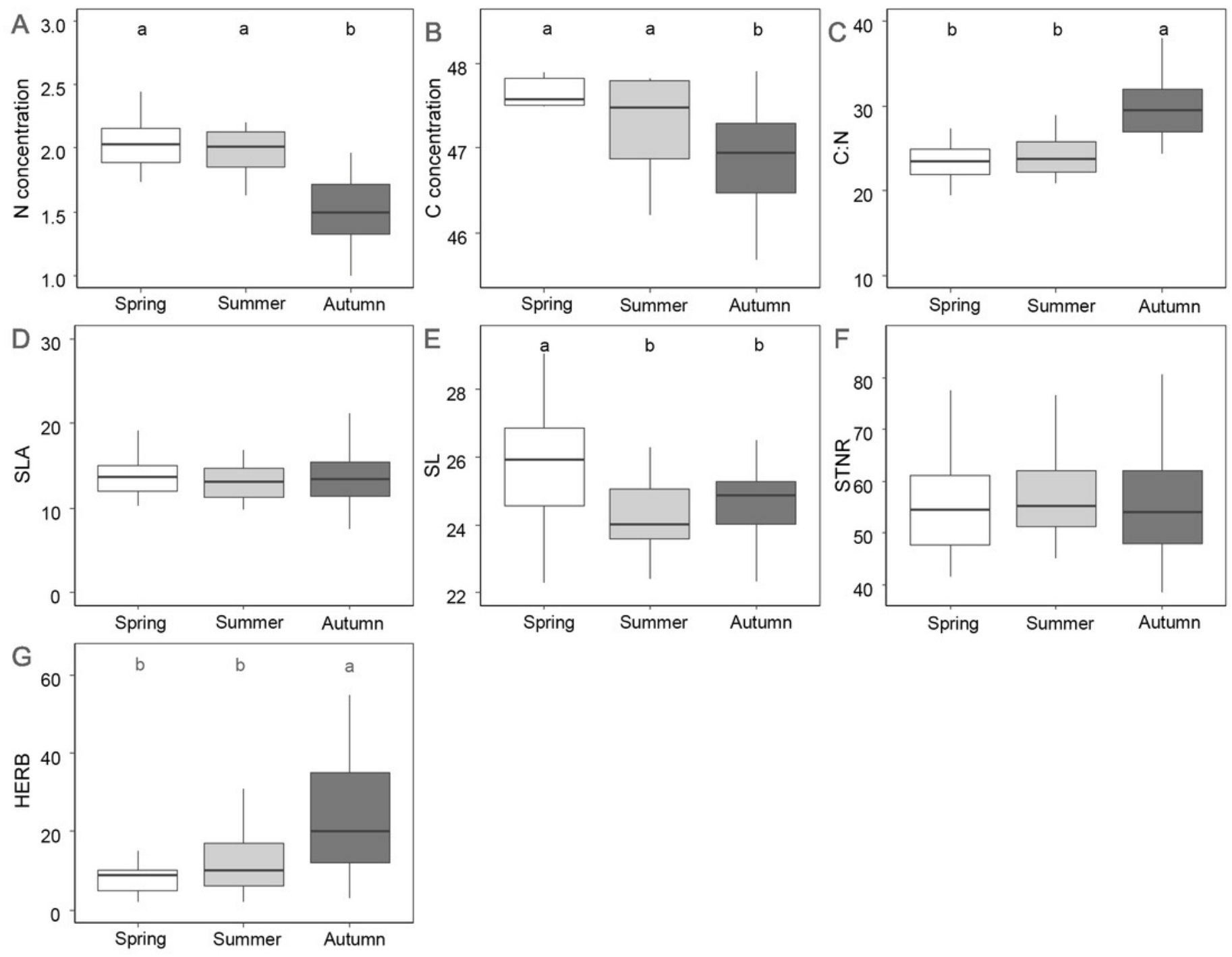
Figure 2

CCA analysis of endophytic communities across the three seasons

CCA analysis of endophytic communities across a temporal sequence (spring: blue dots; summer: green dots; autumn: red dots) and plant foliar traits. CCA was calculated with the following plant foliar traits: HERB = level of herbivory; STNR = number of stomata; SLA = specific leaf area; $\mathrm{SL}=$ length of stomata; $\mathrm{N}=$ leaf nitrogen content; $\mathrm{C}=$ leaf carbon content.

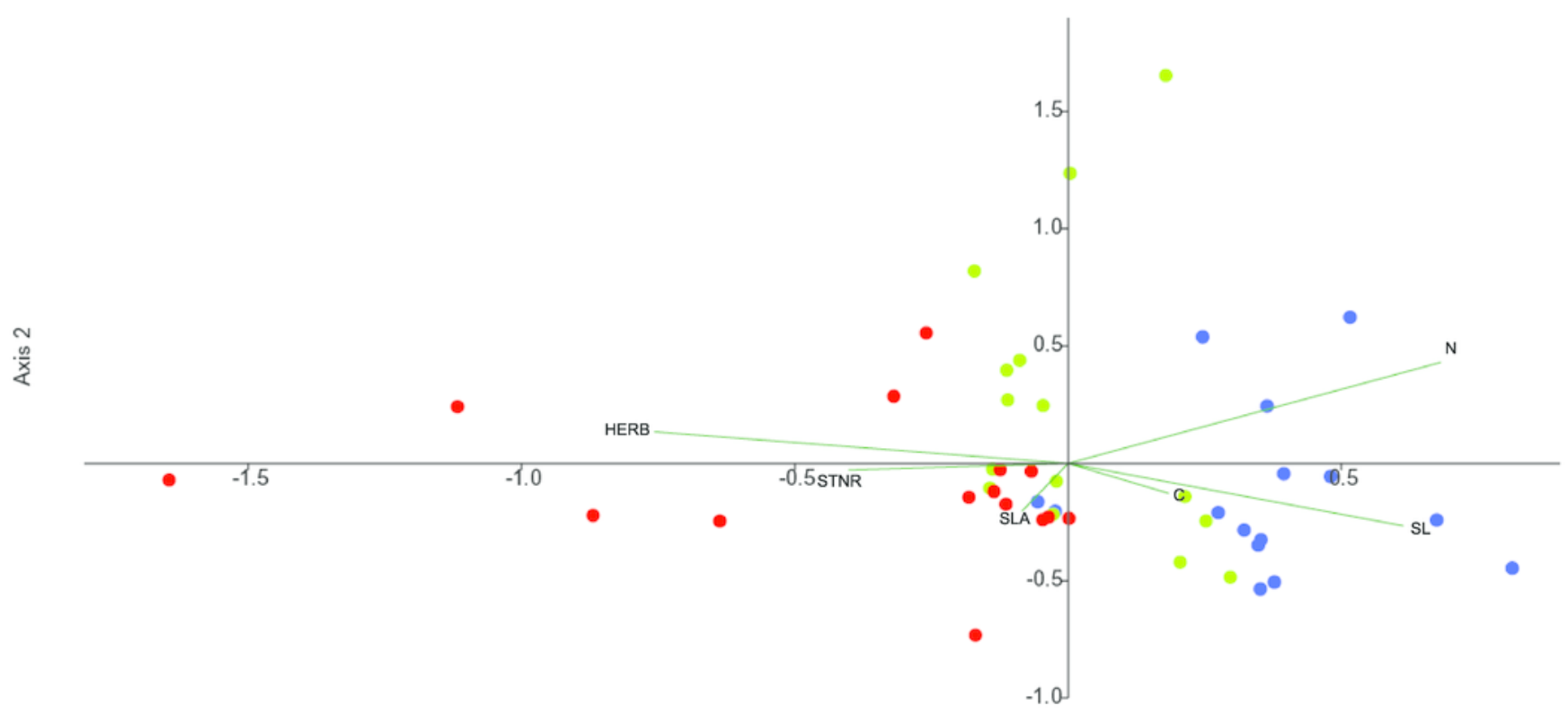

Axis 1 


\section{Table $\mathbf{1}$ (on next page)}

NPMANOVA of the endophytic community structures

$P$ value results from Non-Parametric MANOVA (NPMANOVA) with Bonferroni corrected $p$ value among endophytic bacterial communities across the three seasons (Bray-Curtis dissimilarity). 
1 Table 1 Results of linear mixed effect models for each trait $(\mathrm{N}=$ leaf nitrogen content, $\mathrm{C}=$ leaf

2 carbon content, $\mathrm{C}: \mathrm{N}=\mathrm{C}: \mathrm{N}$ ratio, $\mathrm{SLA}=$ specific leaf area, $\mathrm{SL}=$ stomatal length, $\mathrm{STNR}=$ stomatal

3 number, HERB = herbivory level). Each single trait was analyzed as response variable, season as

4 fixed variable and branches nested in the respective trees as random variable. The basic level

5 (intercept) corresponds to the spring season.

6

\begin{tabular}{|c|c|c|c|c|c|c|}
\hline Trait & $\begin{array}{l}\text { Fixed } \\
\text { effect }\end{array}$ & Value & Std.Error & $\mathrm{DF}$ & t-value & p-value \\
\hline \multirow[t]{3}{*}{$\mathrm{N}$} & (Intercept) & 2.04 & 0.07 & 28 & 30.67 & 0.00 \\
\hline & Summer & -0.07 & 0.09 & 28 & -0.85 & 0.41 \\
\hline & Autumn & -0.57 & 0.09 & 28 & -6.51 & 0.00 \\
\hline \multirow[t]{3}{*}{$\log (C)$} & (Intercept) & 3.86 & 0.00 & 28 & 882.56 & 0.00 \\
\hline & Summer & -0.01 & 0.00 & 28 & -1.68 & 0.10 \\
\hline & Autumn & -0.02 & 0.00 & 28 & -4.90 & 0.00 \\
\hline \multirow[t]{3}{*}{$\log (C: N)$} & (Intercept) & 3.16 & 0.05 & 28 & 69.09 & 0.00 \\
\hline & Summer & 0.03 & 0.06 & 28 & 0.54 & 0.59 \\
\hline & Autumn & 0.33 & 0.06 & 28 & 5.82 & 0.00 \\
\hline \multirow[t]{3}{*}{ SLA } & (Intercept) & 13.98 & 0.99 & 28 & 14.05 & 0.00 \\
\hline & Summer & -0.84 & 1.26 & 28 & -0.66 & 0.51 \\
\hline & Autumn & 0.97 & 1.26 & 28 & 0.77 & 0.45 \\
\hline \multirow[t]{3}{*}{ SL } & (Intercept) & 25.69 & 0.58 & 28 & 44.00 & 0.00 \\
\hline & Summer & -1.66 & 0.31 & 28 & -5.44 & 0.00 \\
\hline & Autumn & -1.49 & 0.31 & 28 & -4.87 & 0.00 \\
\hline \multirow[t]{3}{*}{ STNR } & (Intercept) & 55.48 & 3.87 & 28 & 14.35 & 0.00 \\
\hline & Summer & 2.37 & 1.72 & 28 & 1.38 & 0.18 \\
\hline & Autumn & 0.81 & 1.72 & 28 & 0.47 & 0.64 \\
\hline \multirow[t]{3}{*}{$\log (\mathrm{HERB})$} & (Intercept) & 2.08 & 0.13 & 28 & 16.29 & 0.00 \\
\hline & Summer & 0.39 & 0.17 & 28 & 2.30 & 0.03 \\
\hline & Autumn & 0.88 & 0.17 & 28 & 5.16 & 0.00 \\
\hline
\end{tabular}




\section{Table 2 (on next page)}

Linear mixed effect models for each leaf trait

Results of linear mixed effect models for each trait $(\mathrm{N}=$ leaf nitrogen content, $\mathrm{C}=$ leaf carbon content, $\mathrm{C}: \mathrm{N}=\mathrm{C}: \mathrm{N}$ ratio, $\mathrm{SLA}=$ specific leaf area, $\mathrm{SL}=$ stomatal length, $\mathrm{STNR}=$ stomatal number, HERB = herbivory level). Each single trait was analyzed as response variable, season as fixed variable and branches nested in the respective trees as random variable. The basic level (intercept) corresponds to the spring season. 
1 Table $2 P$ value results from Non-Parametric MANOVA (NPMANOVA) with Bonferroni

2 corrected $p$ value among endophytic bacterial communities across the three seasons (Bray-Curtis 3 dissimilarity).

4

\begin{tabular}{lll}
\hline Seasons & Summer & Autumn \\
\hline Spring & 0.0804 & 0.0009 \\
Summer & $/$ & 0.2484 \\
\hline
\end{tabular}

5

6 


\section{Table 3(on next page)}

LEfSe analysis showing the main OTU biomarkers characterizing each single season.

OTU biomarkers characterizing each single season on the basis of the Linear Discriminant Analysis effect size. 
1 Table 3 OTU biomarkers characterizing each single season on the basis of the Linear Discriminant 2 Analysis effect size.

3

\begin{tabular}{|c|c|c|c|}
\hline$\overline{\text { OTU }}$ & Season & LDA-score & p-value \\
\hline OTU620 & Autumn & 3.22 & 0.033 \\
\hline OTU660 & Autumn & 3.51 & 0.016 \\
\hline OTU713 & Autumn & 3.26 & 0.043 \\
\hline OTU833 & Autumn & 2.93 & 0.043 \\
\hline OTU582 & Autumn & 4.05 & 0.000 \\
\hline OTU600 & Autumn & 3.24 & 0.035 \\
\hline OTU1160 & Autumn & 2.83 & 0.039 \\
\hline OTU640 & Autumn & 3.09 & 0.034 \\
\hline OTU850 & Autumn & 3.06 & 0.035 \\
\hline OTU222 & Spring & 4.38 & 0.000 \\
\hline OTU454 & Spring & 4.00 & 0.000 \\
\hline OTU671 & Spring & 3.07 & 0.043 \\
\hline OTU530 & Spring & 3.15 & 0.004 \\
\hline OTU286 & Spring & 3.18 & 0.007 \\
\hline OTU361 & Spring & 3.90 & 0.000 \\
\hline OTU213 & Spring & 2.95 & 0.014 \\
\hline OTU547 & Spring & 3.65 & 0.043 \\
\hline OTU238 & Spring & 3.68 & 0.050 \\
\hline OTU383 & Spring & 3.23 & 0.043 \\
\hline OTU474 & Spring & 3.68 & 0.043 \\
\hline OTU654 & Spring & 4.36 & 0.004 \\
\hline OTU519 & Spring & 3.79 & 0.024 \\
\hline OTU350 & Summer & 3.08 & 0.008 \\
\hline OTU575 & Summer & 3.27 & 0.042 \\
\hline OTU573 & Summer & 3.54 & 0.030 \\
\hline OTU316 & Summer & 2.98 & 0.014 \\
\hline OTU842 & Summer & 2.67 & 0.043 \\
\hline OTU598 & Summer & 3.13 & 0.015 \\
\hline OTU662 & Summer & 3.16 & 0.030 \\
\hline OTU666 & Summer & 2.87 & 0.014 \\
\hline OTU529 & Summer & 3.17 & 0.004 \\
\hline OTU995 & Summer & 2.91 & 0.014 \\
\hline OTU727 & Summer & 2.79 & 0.043 \\
\hline OTU1119 & Summer & 2.70 & 0.014 \\
\hline OTU564 & Summer & 2.79 & 0.043 \\
\hline OTU634 & Summer & 2.82 & 0.043 \\
\hline
\end{tabular}


